\title{
Selection of Sites for Slit-skin Smears
}

\author{
HAIDAR ABU AHMED*, AYELE BELEHU, GERALD STONER, \\ JACOB TOUW and TSEHAI ATLAW
}

Armaeur Hansen Research Institute, P.O. Box 1005, Addis Ababa, Ethiopia

\begin{abstract}
The results of slit-skin smears from 18 untreated lepromatous leprosy patients showed high bacteriological index (BI) and morphological index (MI) in the ears, fingers, face, buttocks and toes. Need for standardization of site of smearing is stressed. The ears, fingers, face and buttocks are suggested as standard sites for slit-skin smearing for diagnosis, follow-up and assessment of chemotherapy.
\end{abstract}

\section{Introduction}

The bacteriological status of leprosy patients is usually assessed by the slit-skin smear method introduced by Wade (1963). A detailed description of the method is given by Cochrane (1964). The bacteriological index (BI) is used as a semiquantitative assessment of the bacterial load in the sites from which smears are taken (Ridley 1964). The morphological index (MI) is the percentage of solid-stained (living bacilli) found in the smear (Waters and Rees, 1962). The MI is assumed to be a sensitive index for assessment of the efficiency of chemotherapy and for the detection of early mycobacterial resistance to antileprosy drugs. The viability of Mycobacterium leprae in slitskin smears can also be estimated by the mouse footpad technique (Pearson, 1975). However, the MI, inspite of all its limitations (Chatterjee, 1973; Chang, 1977), remains the only method for routine estimation of viability of M. leprae in slit-skin smears.

With the increasing importance of dapsone resistance (Pearson et al. 1976, 1977; Waters, 1977), new antileprosy drugs and new combinations of the existing drugs are needed. To obtain a meaningful result from such drug trials there is real need for standardization of the methods of assessment of drug effectiveness.

This study was undertaken to determine the difference in BI and $\mathrm{MI}$ in the smears from different sites on lepromatous leprosy patients. Only untreated patients were studied because these are the ones who might usually be selected in drug trials (Rees, 1975). Six sites which showed the highest BI and MI are suggested as standard sites for slit-skin smearing.

* Present Address: Dr. Haidar Abu Ahmed, Ministry of Health, P.O. Box 303, Khartoum, Sudan.

Received for publication 3 March, 1979

0305-7518/79/040283 + 05/\$02.00/0

○ 1979 British Leprosy Relief Association 


\section{Material and Method}

Slit-skin smears are taken routinely from all new leprosy patients attending the outpatient clinic in the Addis Ababa Leprosy Hospital. Besides the six routine sites, namely, ear lobe, face, arm, back, buttock and legs, smears were taken from the dorsum of the index finger and the big toe. There was no selection of obvious lesions at the site of these smears. They were stained by a standard Ziehl-Neelsen technique (heat fixation, carbol fuchsin for $10 \mathrm{~min}$, differentiation in $10 \%$ sulphuric acid for a few sec, counterstaining with brilliant green for 5 min). All smear preparation, staining and reading was done by the same technician who does the routine laboratory work. The BI is recorded for each site according to Ridley's scale (Ridley 1964) and the MI as the percentage of the morphologically solid-stained bacilli found in the smear.

Results from 18 newly diagnosed untreated lepromatous leprosy patients seen over the period May 1978 to January 1979 were examined. All the patients have an average $\mathrm{BI}$ of 2 or more.

TABLE 1

Bacteriological and Morphological Indices from 18 Untreated Lepromatous Leprosy Patients

\begin{tabular}{|c|c|c|c|c|c|c|c|c|}
\hline Indices & Ears & Fingers & Faces & Buttocks & Toes & Legs & Arms & Backs \\
\hline \multirow{3}{*}{$\mathrm{BI}$} & $4.5^{*}$ & 4.5 & 4.2 & 4.2 & 4.0 & 3.8 & 3.5 & 3.0 \\
\hline & \pm & \pm & \pm & \pm & \pm & \pm & \pm & \pm \\
\hline & 0.1 & 0.1 & 0.1 & 0.1 & 0.1 & 0.1 & 0.1 & 0.2 \\
\hline \multirow{3}{*}{ MI } & 14.3 & 13.0 & 12.5 & 11.8 & 10.8 & 10.2 & 10.6 & 8.3 \\
\hline & \pm & \pm & \pm & \pm & \pm & \pm & \pm & \pm \\
\hline & 0.5 & 0.9 & 1.0 & 1.1 & 0.9 & 0.2 & 1.0 & 0.8 \\
\hline
\end{tabular}

* Mean of 18 readings \pm standard deviation.

\section{Results}

The mean values of BI and MI from the different sites of the 18 patients are shown in Table 1. Comparing all 8 sites the BI and MI were highest in the smears taken from the ears. The finger smears gave BI and MI results as high as the ears in most of the patients and were always higher than in the other sites. Smears from the face and buttocks showed similar BI and MI. The BI and MI of the smears from the toes were lower than those of the fingers but were always more than those from the back which gave the lowest results. There was a direct correlation between $\mathrm{BI}$ and $\mathrm{MI}$ in all sites in all the patients.

\section{Discussion}

Slit-skin smears have been used by different workers both for diagnosis and assessment of efficiency of drug therapy. There has been no uniformity in the selection of skin sites for slit-scraping or in the number of sites scraped. The nasal-scraping which was at one time used routinely (Browne, 1966, 1967; 
Dharmendra, 1967; Doull, 1961) is no longer in general use. The main reasons for exclusion of the nasal smear are the possibility of contamination of smear by non-pathogenic acid fast bacilli (Cochrane, 1965) and hence the possibility of giving a false positive result, variation in the results from different areas within nasal cavity (Davey and Barton, 1973) and the inconvenience the nasal cavity smears caused to the patients.

The number of sites smeared by different leprologists vary widely. Davison (1961) used four sites for follow-up of his patients. Dharmendra (1967), Browne (1959, 1966), recommended six sites as routine for diagnosis. Six sites were also used by Leiker and Carling (1969) and Garrod and Ellard (1968) for assessment of efficiency of drug therapy. Jopling (1965) recommended eight sites as routine for diagnosis. Eight sites were also used by Doull (1961), Browne $(1965,1966,1967)$ for drug assessment and follow-up of patients. Cochrane (1964) recommended eleven sites for diagnosis, while others (Bryceson and Pfaltzgraff, 1973) recommend six to eight sites without specification. Levy (1969) recommended only one site to be smeared.

As leprosy workers differ in their selection of the number of sites smeared, they also differ in the specific sites smeared. Dharmendra used the ear, cheek, chin, right arm, left thigh and nose. Browne (1959) used six sites including the ear lobe, the forehead, cheek, and three active lesions. Cochrane (1964) used two ear lobes, forehead, chin, cheeks and six smears from suspicious lesions. Jopling (1965) recommended two ear lobes and six active-looking lesions.

It has been noticed (Levy 1969) that there is a wide variation both in BI and MI from different sites. Browne (1967) stressed the variation of result due to the technique of taking the smear. In a study by Gideon and Job (1965) the ears were found to have the highest BI followed by the chin, with similar results for the buttocks in males and thighs in females. The arm, chest and back showed the lowest results. Similar findings were repeated by Padma (1965).

Although serial biopsies had been recommended for the assessment of bacteriological changes (Leiker, 1971), the direct skin-slit scrape method has been shown (Izumi, 1971) to be sensitive enough to be used for bacteriological and morphological indices.

The results in this study confirm the previous finding of Gideon and Job (1965) and Padma (1965). The ears, fingers, face, buttocks give the highest BI and MI. There is correlation between BI and MI which confirm the findings of Levy (1969). Smears from the fingers show approximately 30 -fold more bacilli than the back smears (BI 4.5 vs 3 ) and the difference in number of viable bacilli is approximately 50 -fold (MI 14.3 vs 8.3 ). The fingers provide uniformity of sites and are more likely to yield comparable results with repeated smearing. They have also been shown (Ridley et al., 1976) to be the site at which bacilli were most frequently detected.

It is evident that the highest numbers of viable bacilli are in the ears, fingers, face and buttocks. These results provide a rational basis for the selection of standard sites for skin smears. However in relapses and drug resistant cases it is important to smear newly developing lesions which may be in unexpected sites. We recommend that if six sites are to be smeared they be routinely taken from the two ear lobes, the face, the buttocks and two fingers. The problem of variation in the technique of smear taking (McDougall, 1975) 
and the staining problem (Ridley and Ridley, 1971) could be overcome by the use of a single well-trained technician for all patients under study. The use of the recommended standard sites for skin smears should make the BI and MI reliable indices for assessment of new patients and response to antileprosy drugs.

\section{Acknowledgements}

The Armauer Hansen Research Institute is supported by The Norwegian and Swedish Save The Children Organizations and is affiliated with The All Africa Leprosy and Rehabilitation Training Centre (ALERT).

We are grateful for Dr Bernard Naafs and the rest of ALERT clinicians for selecting the patients for this study. We would like also to thank Ato Muzeyin Mohamed for helping with the smears and the other staff of ALERT Laboratory for their co-operation. We are also gratef ul to $\mathrm{W} /$ ro Shitaye Wolde Kidane for typing the manuscript.

\section{References}

Browne, S. G. (1959). Some observations of the bacteriological index in leprosy. Lepr. Rev. 30, 174.

Browne, S. G. (1965). Leprosy in Eastern Nigeria, Reflections on cases diagnosed at Uzuakoli 1959-64. Lepr. Rev. 36, 133.

Browne, S. G. (1966). Some observations on the morphological index in lepromatous leprosy. Int. J. Lepr. 17, 23.

Browne, S. G. (1967). Drug trials in leprosy. Some unemphasized factors. Lepr. Rev. 38, 7.

Browne, S. G. (1971). The bases of chemotherapy and immunosuppression therapy in leprosy. Int. J. Lepr. 39, 406.

Bryceson, A. and Pfaltzgraff, R. E. (1973). Leprosy for Students of Medicine, p. 32. ChurchillLivingstone.

Chang, Y. T. (1977). Are all non-solid $M$. leprae dead? Does a negative finding in the mouse foot pad indicate that there is actually no growth of M. leprae in the animals? Int. J. Le pr. 45, 235.

Chatterjee, B. R. (1973). Non-uniform staining and viability in mycobacteria. Le pr. India, $45,4$.

Cochrane, R. G. (1964). Technique of examination. In Leprosy in Theory and Practice, 2 nd edit., p. 612. Cochrane, R. G. and Davey, T. F. eds. Bristol: John Wright.

Cochrane, R. G. (1965). The diagnosis of leprosy with special reference to tissue defence. Lepr. Rev. 36, 189.

Davey, R. F. and Barton, R. P. E. (1973). Multiple nasal smears in early lepromatous leprosy. Lepr. India, 45, 54.

Davison, A. R. (1961). Six year follow-up of diphenylthiourea treatment. Lepr. Rev. 36, 145.

Dharmendra (1967). Notes on Le prosy, p. 254. Ministry of Health Government of India.

Doull, J. A., Tolentino, J. G., Rodriguez, J. N., Guinto, R. S., Rivera, J. N., Fernandez, J. V. and Mabalay, M. C. (1961). Clinical evaluation studies in lepromatous leprosy. Int. J. Lep. 29, 291.

Garrod, J. M. B. and Ellard, G. A. (1968). Appearance of resistance during prolonged treatment of leprosy with thiambutosine. Lepr. Rev. 39, 113.

Gideon, H. and Job, C. K. (1965). Skin smears in leprosy. Lepr. India 37, 74.

Izumi, S. (1971). Statistical calculations of the confidence interval and significant difference ranges of the morphologic index. Int. J. Lepr. 39, 852.

Jopling, W. H. (1971). Handbook of Leprosy. Heinemann.

Leiker, D. L. and Carling, D. (1969). Second trial of low dosage of DDS in lepromatous leprosy. Lepr. Rev. 40, 54.

Leiker, D. L. (1971). Assessment of bacteriological changes in leprosy based on serial biopsies. Lepr. Rev. 42, 121.

Levy, L. (1969). Uniformity of the solid ratio of Mycobacterium leprae from lesion to lesion. Int. J. Lepr. 37, 416. 
McDougall, A. C. (1975). The diagnosis of leprosy: Clinical and bacteriological. Lepr. Rev. 46, 79. Padma, M. N. (1965). Choice of site for routine smearing Lepr. India 37, 87.

Pearson, J. M. H. (1975). A simplification of the mouse foot-pad infection using Mycobacterium leprae from skin scrapes. Le pr. Rev. 46, 105.

Pearson, J. M. H., Ross, W. F. and Rees, R. J. W. (1976). DDS resistance in Ethiopia. A progress report. Int. J. Lepr. 44, 140.

Pearson, J. M. H., Haile, G. S. and Rees, R. J. W. (1977). Primary dapsone resistant leprosy. Lepr. Rev. 48, 129.

Rees, R. J. W. (1975). Chemotherapeutic trials and their assessments. Le pr. Rev. 46, (Suppl.) 17.

Ridley, D. S. (1964). Bacterial indices. In Leprosy in Theory and Practice, 2nd edit., p. 620. Cochrane, R. G. and Davey, T. F., eds. Bristol: John Wright.

Ridley, M. J. and Ridley, D. S. (1971). Stain Techniques and the morphology of Mycobacterium leprae. Lepr. Rev. 42, 88.

Ridley, M. J., Jopling, W. H. and Ridley, D. S. (1976). Acid fast bacilli in the fingers of long treated lepromatous patients. Lepr. Rev. 47, 93.

Wade, H. W. (1963). The examination of skin lesions for bacilli. Int. J. Lep. 31, 240.

Waters, M. F. R. and Rees, R. J. W. (1962). Changes in the morphology of Mycobacterium leprae in patients under treatment. Int.J. Lep. 30, 266.

Waters, M. F. R. (1977). Management of complications of sulphone therapy. The 1st International Workshop on Chemotherapy of Leprosy in Asia, 37-52. Manila, Philippines. 